\title{
Scrutinizing the Parallel line between Religion and Politics: Christian Ethical Moral Point of View
}

\author{
Omojuwa Ayodele Iyabo
}

\begin{abstract}
There are many people who believe that a Christian should not get mixed up in politics and that politics is a dirty game that Christians should have no part in it. There are others who believe that Christians in responsible positions can do great good and that political power should not be allowed to be a monopoly of those who might abuse it. Moreover, a Christian politician can persuade his fellow citizens to raise their standards. Wilberforce and his friends abolished slave trade, Shaftesbury and his friends prevented the abuse of child labour. In line with the above, the concern of this paper therefore is to find out which of these two opinion is right by scrutinizing the Christian religious text - the Bible, Christians influence, moral law, layman's witness and the church towards politic. This paper through descriptive survey highlighted the opinion of the stakeholders in Christian religion such as Pastors, Evangelists, Deacons and Deaconesses concerning their option about the relationship between religion and politics. The study was carried out in ten Local governments in Lagos state. Stratified sampling technique was used to selected the total numbers of forty (40) Pastors, forty (40) Evangelists and twenty Deacons (20) from ten (10) Local Governments on the relationship between religion and politics. The outcome of the survey buttress the fact that personal preparation for the kingdom of God is here on earth and it includes the following: Vote in a general or local election or join a political party, become an elected Representative.
\end{abstract}

Index Terms - Religion, Politics, God Manifestos, Public good, Quality of life.

\section{INTRODUCTION}

Highlight Many people believe that politics is a dirty game and that Christians should have no part of it. There are other who feel exactly the opposite. Many Christian believe most strongly that a Christian should not get mixed up in politics.. They also opines that to be of any use in anything one must be involved. Salt is only useful if it is doing its job of flavouring and purifying. They believe that Christians in responsible positions can do great good and that political power should not be allowed to be a monopoly of those who might abuse it. Therefore this paper intends to find answers such questions as: Should a Christian take any part in politics?' Should he or she: Vote in a general or local election? Join a political party? Become an elected representative? Join in political demonstrations or pressure groups? What is really expected of a Christian? What is the right thing to do? In answering these germane questions, this paper will scrutinizing the activities of the various stakeholders in Christian religion such as the Bible,

Omojuwa Ayodele Iyabo, Department of Arts and Social Sciences Education, Faculty of Education, University of Lagos
Christians influence, moral law, layman's witness, the church and the society towards politic and Christianity.

\section{A. Politics}

Politics refer to the processes by which people and groups acquire and exercise power. We commonly think of politics as a feature of governments. But there is also politics in religious groups, educational groups, and scientific groups in friendship groups and families. ${ }^{1}$ When power is organized and wielded through democratic, authoritarian, or totalitarian means, depending on how much participation states allow from citizens and how much control is exercised over the everyday lives of citizens. Though democratic governments appear to be organized in the interests of average

C Merril, The Handy Bible Dictionary and Concordance. Zondervan Publishing House Michigan. 1983, p. 34 says "citizen, social scientist are not in agreement about how "democratic" such state are. Individuals and groups who control critical resources, rewards, punishments, and persuasive communications are able to dictate the way social life is ordered. To command key organizations and institutions is to command people. Thus power is the bedrock of social organization

\section{B. God's Point of View}

'Everything so far in this paper has been looked at from a purely human standpoint. The phrases used include expressions such as "the public good", "the quality of life", and "improving the lot of mankind". Now these expressions are all very well if you are a humanist. If you don't believe in God, and you think that man is the author of his own destiny, then it's perfectly reasonable for you to believe that we can manage our own political affairs in a way which will bring about a better future for the world.

But what about God's instructions? What about the teachings of Jesus Christ? Surely, if we claim to be Christians, followers of Christ, then we cannot leave them out of our considerations. Quite the opposite, in fact, we must look very carefully at what they tell us. Christians believe that it is only God's view on this subject that matters - as with every other aspect of our lives. So we must turn to the Bible to read what He has to say about our relationships with the societies in which we live. What then does the Bible have to say about the Christian and Politics? What is the positive teaching of the Word of God?

\section{C.Three Bible Principles}

Birkhause, describes how the Bible has given a clear teaching on this subject. He pinpoints the three principles we must consider. Briefly summarized, these are: 
$\square$ God rules in the kingdom of men

$\square$ God has His own political manifesto for us

$\square$ We should follow the personal example and teaching of Jesus $^{2}$

In our own view, it is vital for Christians to understand these principles. They will help us to work out exactly how we should respond to calls to vote or become more deeply involved in the political process of the country in which we live. $^{2}$

\section{D.First Principle: "God rules ..."}

God's claim is that $\mathrm{He}$ is king - King over all who worship Him now, and King in the past over the nation of Israel. He called the children of Israel to be "a kingdom of priests, a holy nation" (Exodus 19:6). Other nations and their leaders, particularly those surrounding Israel, were influenced by God, often without knowing the part they played in His purpose. One of these was king Nebuchadnezzar, an autocratic ruler of ancient Babylon who lived six hundred years before Christ. Like modern humanists who think that people can improve the world by their own devices, he refuted the supremacy of the God of the Bible in the control of human affairs. The Book of Daniel, in the Old Testament, gives us a picture of this great Eastern monarch full of pride at his own achievements. We read of him boasting out loud: "Is not this great Babylon, which I have built by my mighty power as a royal residence and for the glory of my majesty?" (Daniel 4:30) However, Nebuchadnezzar had a hard lesson to learn; three times in this same chapter the all important principle is repeated that: "The Most High rules the kingdom of men, and gives it to whom he will". To reinforce this principle, Nebuchadnezzar, the great ruler, was suddenly and dramatically struck down with mental illness, was driven away to make his home with animals, and was deprived of his kingdom until he humbled himself before God. Nebuchadnezzar rose from the most humble background to be the leader of a great empire. The world saw him as a man who succeeded through his own abilities, yet his life was ordered by God to teach us that God, and not man, is ultimately in control. When Nebuchadnezzar had his sanity restored by God, he was honest enough to acknowledge these lessons. "At the end of the days I, Nebuchadnezzar, lifted my eyes to heaven, and my reason returned time, and I blessed the Most High, and praised and honoured him who lives for ever ... he does according to his will in the host of heaven and among the inhabitants of the earth; and none can

\section{E.The Principle Still Applies}

Now you may wonder whether all this history is relevant to the politics of the early 21 st century. Surely this first Bible principle makes it clear that this really is the case. "The Most High rules the kingdom of men, and gives it to whom he will", holds true today just as it did over two thousand years ago. The true Christian, the Bible-based believer, understands that God, and not man, is still in control of human affairs. Throughout the Bible, we are shown how the tangled web of local, national, and international politics so many aspects of which are hidden even from those directly involved - is all in God's good hands, both in history and in the contemporary

world. "His dominion", said Nebuchadnezzar, "is an everlasting dominion". God never changes: this Bible principle still applies today, and it applies whether we recognise it or not.

Wayne Grudge, a theologian, also highlights Paul the Apostle teaching on the fact that all the power that be are ordained of God (Romans 13:1). This was also taught by Peter (1 Peter 2:13-17), and by Jesus Christ in His famous saying, 'Render to Caesar the things that are Caesar's, and to God the things that are God's. (Mark 12:17). In the context, the expression, the power that be refers to government and the primary purpose of government is to maintain order, to restrain and punish evil and to reward good. ${ }^{3}$

To do this, governments do not have to be perfect. Government in the day of Christ and the apostles were imperial and arbitrary, not nationalist or democratic. Their governors were unjust and took bribes, and their tax collectors took more than their due. But the Christians were told by Christ and the apostles to obey them unless they interfered in matters of faith. If Christian were forbidden by government to preach the gospel or told to worship the emperor then, they disobeyed. As Peter said, 'We ought to obey God rather than men' (Acts 5:29). In most country in the world the Christian has about as much chance of becoming a part of government as Peter had of replacing Pontius Pilate or Paul had of replacing Festus or Felix. Their duty of obedience to lawful commands is the limit of the Christian involvement in politics. In countries where the ruling party is atheistic or committed to another religion, the Christian cannot be a member and is effectively excluded from politics and power. He may still, like Joseph or Daniel, act as an adviser, but he will not allow himself to be committed to the beliefs or shibboleths of the ruling party. Apostle Paul said Christian should not be messmate with unbelievers, and, 'Therefore come out of them and be separate from them, says the Lord, and touch nothing unclean' ( $2^{\text {nd }}$ Corinthians 6:14, 17). Read in this way the passage might seem to suggest that we should opt out of any political organization, profession, club etc to which non Christians belong. But if the passage is carefully studied alongside such a story as the parable of the Good Samaritan (Luke 10:29-37) and the teaching of Jesus about salt and light in Matthew 5:13-16, I believe it w on a ill be seen that the general tenor of scripture is on involvement, not on separation. Separation depend on a close walk with the Lord, not on external condition.

A Christian politician must be involved in every aspect of the politics positively. Not everyone can become the president. Any more than every catholic can be a Pope. But in a political part like in a church there is a minimum requirement for a faithful member. The early Christians were told not to neglect to meet together, as well as the habit of some (Hebrews 10:25). Today the same thing might well be said to political parties. Christians certainly ought to attend political meetings. This is not in order to oppose or antagonize the members but that the Christians may well find themselves voting and working with them on some issues, and to bring God's justice into every situation. The Bible has much to say about political parties and patricians, government and the governs, state and the nation and attitude to all these. God hold a good concordance and search out the truth of all. 


\section{Ezekiel 34 will make a fair start.}

\section{SECOND PRINCIPLE: God Has A Political MANIFESTO}

The second principle arises from the first. God is in control of our world; but He is not like some mythical Greek god who amuses himself by tampering with our fate and who makes life difficult for us for no particular reason. Far from it! Instead, the Bible shows us very clearly that our God - the God of the Old Testament and of the New - has His own political agenda. He has planned the ultimate solution for all the problems of our world; and it is for that perfect remedy that every true Christian should pray, as Jesus taught his disciples to say: ${ }^{4}$

"Our Father who art in heaven, Hallowed be thy name. Thy kingdom come. Thy will be done, on earth as it is in heaven". (Matthew 6:9-10)

To put more weight on this opinion, the study employed descriptive survey design to collect data from the target population of Christian Religion stakeholders such as Pastors, Evangelists, Deacons and Deaconesses concerning their option about the relationship between religion and politics. The study was carried out in ten Local governments in Lagos state. Stratified sampling technique was used to selected the total numbers of fourty Pastors (40) and fourty (40) Evangelists from ten (10) Local Governments, the total number of male ministers were twenty-eighth (28), while the total numbers of female ministers were twelve (12) and the total number of Deacons were twenty (20), while the total numbers of Deaconesses were twenty (20)

\section{A.Manifesto 1 - Nebuchadnezzar's Dream}

The first takes us back again to king Nebuchadnezzar. This king had a dream of a giant statue of a man, made of five different metals. In his dream, the statue was knocked over by a stone and

ground into powder by it. The stone then grew into a mountain which filled the whole earth. Perhaps not surprisingly, the king could not understand his dream and he needed the prophet Daniel to tell him its meaning (Daniel 2:36-45). The interpretation he gave is an intriguing and accurate political history of the nation of Israel and the nations which invade it, given in remarkable prophetic detail that can be mapped from Babylon to the present day. The precise identification of these various empires is a fascinating and rewarding subject. However the important point for us now to notice is that (in verses 44, 45) God declares His intention to set up His own kingdom, the establishment of which is foreshadowed by the work of the little stone in the dream:

"The God of heaven (shall) set up a kingdom, which shall never be destroyed: and the kingdom shall not be left to other people, but it shall break in pieces and consume all these kingdoms, and it shall stand for ever." This, in a nutshell, is God's political manifesto.

\section{B. Manifesto 2 - Daniel's Vision}

Later in his life, Daniel had a dream about the fulfillment of this promise. He described it like this:

"I saw in the night visions, and behold, with the clouds of heaven there came one like a son of man, and he came to the Ancient of Days and was presented before him. And to him was given dominion and glory and kingdom, that all peoples, nations, and languages should serve him; his dominion is an everlasting dominion, which shall not pass away, and his kingdom one that shall not be destroyed." (Daniel 7:13-14) Although the language used in the book of Daniel is sometimes difficult to understand, there can be no misunderstanding of this passage. Here is a picture of the Lord Jesus Christ, the Son of Man. He is given authority by his Father to return to the earth and to rule over it. All nations will serve him. What a picture of power and authority this is! When he comes, no-one will be able to resist him.5

\section{C.Manifesto 3 - The Role of Jesus}

Jim Walls pointed our attention to Matthew 26, that it contains the remarkable record of Jesus standing before the High Priest at his trial. Shortly afterwards he will be taken and crucified, but Matthew gives us a picture of him which clearly identifies him with the "stone" of Daniel 2 and the "Son of Man" of Daniel 7. The significance of this particular occasion is underlined by the fact that Jesus is on oath, and on trial for his life, before the highest civil and spiritual authority of first century Israel. The Jewish leaders, who hated Jesus, were trying to catch him on a charge of blasphemy, and wanted him to repeat his earlier claim to be "the Christ, the Son of God" (Matthew 26:63). Jesus, who always spoke the truth, could hardly deny that this was true. "Thou hast said" was his reply. This is a Jewish idiom equivalent to saying: 'You're quite right'. Jesus did not leave it there, however, he went on to identify himself to the High Priest as the one like "the Son of Man" in Daniel ; and he did this by quoting Daniel 7:13 and applying it to himself:

"...nevertheless I say unto you, Hereafter shall ye see the Son of man sitting on the right hand of power, and coming in the clouds of heaven." (Matthew 26:64)

Jesus could hardly have been more explicit. He was telling the Jews that he was indeed the one promised by Daniel who would come to set up an everlasting kingdom on the earth. This is confirmed by the violent response of the High Priest who knew his Old Testament scriptures and who recognized that Jesus was applying Daniel's prophecy to himself. He was appalled at what he considered to be these blasphemous claims by Jesus. "Then the high priest rent his clothes, saying, He hath spoken blasphemy; what further need have we of witnesses?" No further need al all! Jesus is the Son of Man and the stone of Daniel; and he will both destroy the kingdom of men at his coming and receive the eternal kingdom of his Father!

\section{D.Manifesto 4 - But when? (Acts 3)}

The fourth and final Bible passage picks up that important word used by Jesus in Matthew 26:64: "Hereafter". We know for certain that Jesus will be God's appointed ruler in His eternal kingdom. However it is not until the apostles commenced their preaching about Jesus (after his ascension to heaven) that we get some inkling as to when Jesus will finish God's work and fulfil all His manifesto pledges.

According to Gruden, Luke's account in Acts 3 gives us a helpful clue about when the "hereafter" might be. This is only the second time the Christian gospel was preached after the ascension of Jesus, and therefore the message is all the more significant. The preacher is the apostle Peter, who declare 5 
"Repent ye therefore, and be converted, that your sins may be blotted out, when the times of refreshing shall come from the presence of the Lord; and he shall send Jesus Christ ... whom the heaven must receive until the times of restitution of all things, which God hath spoken by the mouth of all his holy prophets since the world began." (Acts 3:19-21)

Peter confirms the good news of the great promises made by God. His was not a new message but a continuation of those things which God had spoken of from the beginning of the world! What greater assurance could there be that God's plan for the world was still on course? This is what true Christians should be preaching about and praying for today the kingdom of God on earth ruled over by His Son Jesus. This is the only political manifesto with which true Christians

should get involved.5 This is the only solution to all the world's problems which God Himself will bring about, whatever men may say or do either to help or hinder Him. "For who hath resisted His will?" (Romans 9:19).

\section{METHODOLOGY}

Using the descriptive method, the study was carried out in ten Local governments in Lagos state. Stratified sampling technique was used to selected the total numbers of forty (40) Pastors, forty (40) Evangelists and twenty Deacons (20) from ten (10) Local Governments on the relationship between religion and politics

\begin{tabular}{|c|c|c|c|c|}
\hline $\mathbf{S} / \mathbf{N}$ & ITEMS & YES & NO & TOTAL \\
\hline 1 & Amuwu Odofin Local Government & $\begin{array}{l}18 \\
(45 \%)\end{array}$ & $\begin{array}{l}22 \\
(55 \%)\end{array}$ & $\begin{array}{l}40 \\
(100 \%)\end{array}$ \\
\hline 2 & Shomolu Local Government & $\begin{array}{l}12 \\
(30 \%)\end{array}$ & $\begin{array}{l}28 \\
(70 \%)\end{array}$ & $\begin{array}{l}40 \\
(100 \%)\end{array}$ \\
\hline 3 & Lagos Island Local Government & $\begin{array}{l}28 \\
(70 \%)\end{array}$ & $\begin{array}{l}12 \\
(30 \%)\end{array}$ & $\begin{array}{l}40 \\
(100 \%)\end{array}$ \\
\hline 4 & Mushin Local Government & $\begin{array}{l}30 \\
(75 \%)\end{array}$ & $\begin{array}{l}10 \\
(25 \%)\end{array}$ & $\begin{array}{l}40 \\
(100 \%)\end{array}$ \\
\hline 5 & Bariga Local Government & $\begin{array}{l}32 \\
(80 \%) \\
\end{array}$ & $\begin{array}{l}8 \\
(20 \%) \\
\end{array}$ & $\begin{array}{l}40 \\
(100 \%)\end{array}$ \\
\hline 6 & Alimosho Local Government & $\begin{array}{l}16 \\
(40 \%) \\
\end{array}$ & $\begin{array}{l}24 \\
(60 \%)\end{array}$ & $\begin{array}{l}40 \\
(100 \%)\end{array}$ \\
\hline 7 & Agege Local Government & $\begin{array}{l}36 \\
(90 \%) \\
\end{array}$ & $\begin{array}{l}4 \\
(10 \%)\end{array}$ & $\begin{array}{l}40 \\
(100 \%)\end{array}$ \\
\hline 8 & Kosofe Local Government & $\begin{array}{l}32 \\
(80 \%)\end{array}$ & $\begin{array}{l}8 \\
(20 \%) \\
\end{array}$ & $\begin{array}{l}40 \\
(100 \%)\end{array}$ \\
\hline 9 & Ibeju-Leki Local Government & $\begin{array}{l}22 \\
(55 \%)\end{array}$ & $\begin{array}{l}18 \\
(45 \%)\end{array}$ & $\begin{array}{l}40 \\
(100 \%)\end{array}$ \\
\hline 10 & Etiosa Local Government & & & \\
\hline
\end{tabular}

\section{Source: field survey 2014.}

$\mathrm{T}$ opinion of the respondents here corroborate that of the Bible which tells us that the Word of God contains this divine political manifesto for the earth's future. It is a manifesto full of promises which God Himself will deliver, and towards which $\mathrm{He}$ is constantly at work in our world. Moreover, He gives us an absolute guarantee that what $\mathrm{He}$ has promised, he will deliver. "But truly, as I live ... all the earth shall be filled with the glory of the LORD." (Numbers $14: 21)$

\section{IV. . ThiRd PRINCIPLE: The EXAMPLE AND TEACHING OF JESUS}

The personal example and teaching of Jesus Christ is of great importance to those who think about this subject. How did Jesus act and speak when faced with the political issues of his day? What were his responses and what did he expect of his disciples as they followed him? Perhaps most important of all, what does Jesus expect of us today?

\section{A.Jesus Christ Himself: Rendering unto Caesar?}

Thankfully we are not left in doubt about how Jesus behaved when faced with political questions. There are many occasions recorded in the gospels when his contemporaries asked for his opinions about such matters, or wanted to embroil him (often for their own ends) in political issues. And yet, on every one of these occasions, Jesus steadfastly refused to be drawn into the arguments, or to commit himself to one party or another in the contemporary political scene. His attitude towards the state was based on conscientiously obeying the laws of the land and no more - and even then only if that did not conflict with his duty towards God. ${ }^{6}$

Luke 20 contains one particularly important incident of this kind. The enemies of Jesus were keen to draw him into declaring his political allegiance. Was it right or wrong for a Jew to pay taxes to Rome? Here was the perfect opportunity for Jesus to show his solidarity with his people, downtrodden as they were by the cruel power of Rome and the rapacity of their greedy tax-gatherers. Yet the answer of Jesus rose right above the political issues, avoided the minefield of controversy, and placed the answer firmly back on the individual conscience. .

"Then render to Caesar the things that are Caesar's, and to God the things that are God's." (Luke 20:25)

What a wonderfully balanced response this is for every disciple of Jesus Christ! His answer holds true for every generation - not just for oppressed Jews in his day. If we truly gave to God everything we should, then we should have very little time, energy, or resource to devote to anyone or anything else. So while the reply of Jesus may seem to be just a 
brilliant piece of verbal diplomacy to get him out of a tricky situation, it is actually a searching challenge to every would-be Christian. Where is our true allegiance and whose claims upon us take precedence? If we are really committed to God, then it is impossible for us to balance an interest in this world with our discipleship. God wants whole hearted believers whose political interests lie solely in the coming Kingdom of God for: "No one can serve two masters; for either he will hate the one and love the other, or he will be devoted to the one and despise the other." (Matthew 6:24)

\section{B. 'Society's Point of View'}

Our society expects its citizens to take part in the political process. It is also true that there are many politicians who enter politics with the conviction that they can improve the lot of mankind. In the recent history of the Western world, a number of governments have had remarkable success in improving the quality of life of the average individual. For instance, the establishment of the Welfare State in the UK, and the post-war German economic miracle are obvious examples of this. There are also many leading politicians in Nigeria who are happy to be known as practicing Christians, and who seem to have no qualms of conscience about the exercise of power in the interests of the public good. Some political parties even include the description 'Christian' in their party's name. All these points certainly look like reasons for Christians to be willing to play a responsible part in the way their county is managed, especially if it is 'for the right motives'. So why do Christians take such a different view of these important issues?

\section{C.Christian Influence}

We need to $t$ remember that the influence of Christians inside and outside politics is enormous. It was the Christian church which survived and not the Roman Empire, and Christian ideals which were gradually accepted through Europe rather than the ideals of the Romans. So even where Christian have no place in politics, they can by their ideals and example gradually change the political climate in which they live. We are taught to pray for rulers and those in authority. We are also taught to pray that God's will be done on earth as it is in heaven. W e should believe that God can answer the prayer he has taught us. ${ }^{1}$

But Christ also taught that 'whoever takes the sword shall perish with the sword' (Matt.26:52). It is not only lack of faith but disobedient to attempt a violent overthrow of government, even a corrupt and arbitrary government like that of Nigeria and many other African countries. In most countries of the world where Christian influence has prevailed there are democratic governments and a Christian can stand as a candidate for election to any post. Many Christians feel that they have no right to impose Christian principles on those who are not Christians. They also feel that it would be wrong to those principles for something else. So they feel that they cannot accept political responsibility. Their problem is that they do not distinguish between the moral law under which man answers to God and the civil law under which Christian answer to our fellow men.

\section{D.The Moral Law.}

When Christ said that divorce was contrary to God's will it was pointed out to him that Moses had allowed it, and who was he to contradict? His answer was that Moses had allowed divorce for the hardness of their hearts, 'but from the beginning it was not so' (Matthew 19:8). Moses was the civil order. He gave Israel the Ten Commandments, which embody the moral law. But he also gave laws of the land rules for the people of Israel to be enforced by their rulers. If a man loves his wife and he loves himself, according to the moral law he will not divorce her. But hard-hearted men, though they cannot be persuaded to keep the moral law, still may be persuaded by the penalty of the civil law not to throw out their wives without going through a proper for of divorce in which the law will protect the wife's rights. Field opines that a Christian politician who passes bill allowing divorce does not deny his principles any more than Moses denied his. Both are doing their best in the circumstances. But a Christian politician can also try to persuade his fellow-citizens to raise their standards. Wilberforce and his friends abolished slave trade, Shaftesbury and his friends prevented the abuse of child labour. ${ }^{2}$ Both groups acted as a Christian politician on Christian principles. ${ }^{3}$

All countries need some ultimate moral standard. No country can survive for long unless there is a moral basis to its laws, a basis on which men can agree. Those who are not Christian try to make up their own moral basis. But why should anyone agree with them? They tell people not to be greedy and no one takes too much notice. It needs more than exhortation to turn back greed, to curb violence, to make the rich pay taxes, to help the poor, to make the strong stand aside, and, to help the weak. The Christian in politics can contribute his knowledge of a divinely revealed moral order which men are happier if they keep and which has been applied and tried in all kinds of society for two thousand years. But according to Frederick Catherwood, Politic is about power, and power, like money, can corrupt. Power is government. It profoundly impacts our interpersonal relationships, our social relationships, and our relationship with God. Nothing touches us more profoundly for good or for ill than power.

Power can destroy or create. The power that destroys demands ascendency; it demands total control. It destroys relationship; it destroys trust; it destroys dialogue; it destroys integrity. And this is true whether we look through the macrocosm of human history or the microcosm of our own personal histories.

Power can be an extremely destructive thing in any context, but in the service of Christianity it is downright diabolical. Christian power can destroy in a way that no other power can. Power corrupts, and absolute power corrupts absolutely, and this especially true in Christianity. The Christian in politics must not regard power as his supreme objective. In his attempts to be elected and gain power for his party he must do nothing against the Christian standards of conduct. If he does, he will destroy his usefulness as a Christian. The saying 'If God be for us, who can be against us?' is not a guarantee that Christian will win elections without trying. But Christians have found that a reputation for honourable behaviour does not in the end hinder, and often helps them, to get elected.

Martin Luther astutely observed, "There are three conversions necessary: the conversion of the hearth, mind, and the purse". ${ }^{11}$ Of these three, it may well be that we find 
the conversation of the purse the most difficult. It is hard for people to talk about money. I recently heard of a couple, both psychologists, who would speak openly and frankly in front of their children about sex, death, and all manner of difficult subjects, but would go into their bedroom and close the door when they wanted to talk about money. In a survey of psychotherapist in which they listed things they should not do with their parents, it was found that talking about their income and expenditure was a greater taboo than warnings, touching, kissing, or even sexual intercourse. Money is indeed a forbidden subject of discussion.

Though the Bible gives repeat about the dark side of money, it also contains a stream of teaching on the light side of money. Money is seen as a blessing from God and, even more startling, as a means of enhancing our relationship with God. The Old Testament bear repeated witness to this to this reality. In the creation story we are struck by the refrain that this world that God created is good. The garden of Eden was a lavish provision for the original pair. God great generosity can be seen in his care for Abraham. God said that he would make Abraham's name great and prosper him. He kept his word, for we read that "Abraham was very rich in cattle, in silver, and in gold" (Gen.13:2). Isaac was blessed in similar fashion, so much so that we are told that because of his great wealth "the Philistine envied him" (Gen.26:14). We are told that Job was a man of great wealth and that he was "blameless and upright, one who feared God, and turned away from evil" (Job 1:1). Solomon's great wealth was not viewed as something to be embarrassed about, rather, it was considered as evidence of God's favour (1Kings 3:13). The Bible gives considerable space to cataloging Solomon's riches and the concludes, "Thus King Solomon excelled all the kings of the earth in riches and in wisdom"(1Kig 10:23). The queen of Sheba exclaims, "I did not believe the reports until I came and my own eyes had it, and, behold, the half was not told me, your wisdom and prosperity surpass the report which I had" (1 Kings 10:7).

The New Testament is not devoid of this emphasis. Money is often seen as a way of enhancing our relationship with God and expressing our love for our neighbour. The wise men brought their wealth to the Christ child as a means of worship. Zacchaeus gave generously, and the poor widow gave sacrificially. Wealthy women helped support the band of disciples (Luke 8:2-3). Both Joseph of Arimathea and Nicodemus the used their wealth in the service of Christ (Matt. 27:57-61; John 19:38-42). By teaching us to pray for daily bread, Jesus brought the concern for material provision into intimate relationship with the spiritual life. Material things are not to be despised or thought of as something outside the parameters of true spirituality ${ }^{4}$ Indeed, material provisions are lavish gifts of a bountiful God. In Acts we are told of Barnabas, who was a rue son of encouragement when he used his land investments to aid the early Church (Acts

"Where your treasure is, there will your heart be also. (Matthew 6:21)

No one can serve two masters; for either he will hate the one and love the other, or he will be devoted to the one and despise the other. You cannot serve God and mammon. (Matthew 6:24)

Therefore do not be anxious about tomorrow, for tomorrow will be anxious for itself. Let the day's own trouble be sufficient for the day. (Matthew 6:34)"

All of these things were then summed up by Christ with the
4:36-37). We are also given the wonderful story of Cornelius, who "gave alms liberally to the people, and prayed constantly to God" (Acts 10:2). We are also reminded of Lydia, the seller of purple, who used her status and resources to benefit the early church (Acts 16:14). The Apostle Paul uses the collection for the saints in Jerusalem as an opportunity to teach the spiritual benefits of cheerful giving. (2Cor.8 and 9). He even list giving as one of the spiritual gifts (Rom.12:8). From the brief overview it is clear that the Bible contains a stream of teaching that views politics, power and money in a positive way. Also, it is evident here that closely tied to God's provision is God's ownership.

\section{CONCLUSION}

Our personal response to all this will depend on how much we acknowledge the Bible as the Word of God and how much we are prepared to listen to its message to us. If we refuse to accept that "all Scripture is given by inspiration of God", and that it is able to make us "wise unto salvation through faith which is in Christ Jesus", then Bible teaching about God's control of human affairs will appear meaningless to us. If this is the case then we are justified in making our own fallible political decisions and to make up our own minds as best we may on the basis of what we see and hear in the world around us. But ... we then need to live with the consequences of those decisions, especially when we get them wrong!

Christians believe differently. We accept fully the authority of the Bible and believe that it tells us of the unchanging and everlasting rule of God throughout human history. To unbelievers, a position of complete non-involvement in political affairs seems to be a negative attitude to the political challenges of the world. However, true Christians are men and women who are convinced that God is in control of human affairs, and that His plan and purpose is being worked out on this earth, regardless of what any man may do to thwart it. They believe that such non-involvement is a positive and deliberate statement of allegiance to God, and a complete subjection to His will. ${ }^{12}$ Convinced that God is in control-not man-such people take no part at all in politics. How are we to know which of our leaders is the one God wants to be in power? How shall we be sure, if we cast our vote, that we are voting for the person who is the right one in God's eyes? It is sufficient to know, and to be certain that God's will shall be done "on earth, as it is in heaven". No doubt they remembered how, at the beginning of his ministry, Jesus spelled out to them what these things meant in practice. His discourse is found in Matthew 5-7 and we call it the Sermon on the Mount. In it Jesus gave direct answers to the questions we asked at the beginning of this paper in the following quotations. $^{5}$ 
anxious, saying, 'What shall we eat?' or 'What shall we drink?' or 'What shall we wear?' For the Gentiles seek all these things; and your heavenly Father knows that you need them all. But seek first his kingdom and his righteousness, and all these things shall be yours as well." (Matthew 6:32-33)

In our own view therefore, for the true Christian, nothing is more important than the coming Kingdom but our personal preparation for it here on earth include the following:

Vote in a general or local election or join a political party.

Become an elected Representative.

Join in political demonstrations or pressure groups to make a better world.

\section{REFERENCES}

[1] Birkhause, K. (2010) in Christian Today Magazine. http// www.christian today.com.

[2] Cartherwoos, F. (1998) Money, Sex and Power. Dominion Press, New York

[3] Field, P. (2009) Christian in the World. Westminster Press Philadelphia.

[4] Jim W. (2006) God's Politics: why the Right get it and the Left doesn't get it. http//www.amazonbooks.com.

[5] Grudem, W. (2010) Politics According to the Bible. http//www.amazonbooks.com

[6] Obama, B. (2009) in Jewish Journal of Christian Politics, Culture and Spirituality http//www.questa.com.

[7] Pecknold, C. (2010) Christianity and Politics. http//www.amazonbooks.com 